\title{
PROSES INDUSTRIALISASI DI INDONESIA DALAM PRESPEKTIF EKONOMI POLITIK
}

\author{
Vivin Retno Damayanthi \\ Fakultas Ekonomi Universitas Brawijaya
}

\begin{abstract}
Industrialization has become one of the economic transformation programs in Indonesia. There are many policies implemented to support the programs. This paper will observe the process of industrialization in Indonesia in the perspective of political economy. Furthermore, it also will analyze on how economic policy will support the industrial sector in Indonesia and its role on economic growth.
\end{abstract}

Keywords: Industrialization, Political Economy and Economic Policy.

\section{A. LATAR BELAKANG}

Selama ini, di negara-negara berkembang seperti Indonesia, industrialisasi merupakan 'primadona' dalam usaha pembangunan negaranya khususnya dari strategi perbaikan kondisi perekonomian. Industrialisasi dianggap sebagai strategi sekaligus obat bagi banyak negara. Sebagai strategi, industrialisasi dianggap sebagai proses 'linier' yang harus dilalui dengan sejumlah tahapan yang saling berkaitan dan berurutan dalam transformasi struktur ekonomi di banyak negara. Sementara itu, sebagai obat, industrialisasi dipandang ampuh dalam mengatasi masalah keterbelakangan, kemiskinan, ketimpangan, dan pengangguran. Dimana menurut pandangan ini, diasumsikan bahwa industri yang dikembangkan merupakan industri berbasis padat karya, mengutamakan kompetensi inti daerah (local resources), menimbulkan dampak pengganda (output, pendapatan, tenaga kerja, dan teknologi) yang tinggi, dan membawa regional spillover bagi daerah sekitarnya (Kuncoro, 2007).

Akar intelektual kebijakan industrialisasi yang dikendalikan negara sesungguhnya dimulai pada abad ke-19. Antusiasisme terhadap industrialisasi selanjutnya melanda Jepang dan dunia Barat, yang mendorong ahli sejarah ekonomi mengatakan bahwa apa yang semula tak lebih dari tujuan kebijakan telah berubah menjadi "Ideologi Independensi Ekonomi" yang menghendaki 'Peningkatan posisi negara serta titik berat pada industrialisasi sebagai wahana bagi integrasi nasional' (Claire, 1980; dalam Yustika, 2007:74). Industrialisasi menjadi unsur utama dalam 'Ideologi Pembangunan Nasional' yang tersebar luas di negara-negara sedang berkembang (Seers, 1983; dalam Yustika, 2007: 74).

Industrialisasi merupakan tahap penting dalam usaha negara-negara berkembang meningkatkan kemakmurannya, termasuk juga mengatasi masalah-masalah pengangguran serta meningkatkan produktivitas kerja sebagai salah satu penyebab rendahnya pendapatan. Pada umumnya negara-negara berusaha mengembangkan industri yang dapat menghasilkan dalam waktu relatif pendek serta dapat menghemat devisa. Karena itu, pilihannya kerap kali jatuh pada usaha lebih dahulu mengembangkan industri subtitusi impor. Hal ini dirasakan oleh hampir semua negara berkembang. Oleh karena itu, perkembangan tahap awal relatif cepat, kemudian makin lambat tatkala periode mudah dan dilindungi harus dilepaskan. Ternyata hanya sedikit negara berkembang yang dapat termasuk negara industri baru.

Sesuai dengan misinya, maka sektor industri mempunyai peranan yang penting dalam perekonomian nasional, terutama dalam kaitan dengan pemerataan kesempatan berusaha dan perluasan 
lapangan kerja, sehingga dengan demikian mendapat perhatian yang besar dari pemerintah. Hal ini disebabkan bukan hanya karena perkembangannya yang pesat yang tercermin dari persebarannya, akan tetapi juga dalam kemampuannya memenuhi kebutuhan dalam negeri, peranannya yang cukup besar dalam total ekspor non migas, menciptakan lapangan kerja baru serta kontribusinya menyerap tenaga kerja dalam jumlah yang besar.

Indonesia, sebagai mata rantai negara berkembang juga tidak luput terkena demam industrialisasi tersebut. Semenjak pembangunan ekonomi dimulai secara terencana mulai tahun 1969, Indonesia mulai menggunakan pendekatan strategi Industrialisasi (Ahmad Erani Yustika, 2007). Citacita industrialisasi nasional adalah menciptakan kemakmuran bagi seluruh rakyat, dalam pengertian; kebutuhan barang dan jasa tercukupi, masyarakat punya daya beli, karena penghasilan yang layak disertai produktivitas tinggi, serta ilmu pengetahuan dan teknologi berkembang maju secara adil dan merata. Berdiri sejajar dengan itu, industrialisasi juga bermakna membangun ketahanan ekonomi nasional, sehingga kedaulatan sebagai negara-bangsa nyata terwujud (Dominggus Oktavianus, 2007).

Gagasan industrialisasi nasional sebagai jawaban alternatif patut mendapat sambutan. Jawaban ini, tentu saja, menyertakan perubahan pada dimensi sosial lain seperti pada bidang politik, sosialbudaya, birokrasi, pertahanan-keamanan, lingkungan hidup, dll. Karenanya, akan sangat penting untuk mengetahui bagaimanakah proses industrialisasi di Indonesia terjadi melalui perspektif ekonomi politik.

\section{Industrialisasi Menurut Pandangan Konvensional (Conventional View)}

Tujuan dari bagian ini adalah untuk menggambarkan bagaimana konsep industrialisasi bisa berkembang, dan diterapkan oleh sebagian besar negara di dunia. Dimulai dari pengalaman negaranegara 'Barat' dan kemudian diterapkan pada perekonomian Asia. Bagian ini dimulai dengan menjelaskan apa yang disebut dengan 'universalist trajectory' atau cara-cara industrialisasi bisa tersebar ke seluruh dunia, dan dua mitos yang mendukung pandangan ini, yaitu Konsep Spesialisasi dan Konfergensi; Penggabungan.

Mengapa industrialisasi ditempuh? Menurut Alan Mountjoy dalam Latief (2002), sektor industri mempunyai beberapa keuntungan di banding produksi primer, antara lain :

- Memiliki metode, persaingan, dan output yang lebih fleksibel dari pada sektor pertanian;

- Decreasing return, yaitu situasi di mana setiap penambahan faktor-faktor produksi dan biaya akan diikuti dengan peningkatan produksi semakin menurun yang tidak menguntungkan lagi sehingga harus mengembangkan unit produksi yang baru. Sektor industri manufaktur lebih lambat dari sektor pertanian sebab dalam industri terus-menerus diadakan perbaikan teknologi sehingga efisiensi dan produtivitas semakin tinggi ;

- Kontrol produksi dapat lebih tepat sehingga lebih mudah menyesuaikan antara permintaan dan penawaran. Demikian juga supply atau produksinya lebih elastis atau lebih mudah disesuaikan bila terjadi perubahan permintaan atau perubahan harga;

- Proporsi antara biaya operasi dan biaya tetap lebih baik. Artinya, dalam bidang pertanian, biaya tetap relatif lebih tinggi dari pada biaya operasional sehingga perkembangannya lambat. Dalam industri manufaktur, biaya yang besar diperlukan untuk bahan baku, tenaga, dan jasa-jasa lain. Kesemuanya termasuk biaya operasional.

- Perekonomian yang bersifat industri lebih mampu menyerap banyak tenaga kerja. Karena itu, sasaran umum kebijakan industri antara lain: (a) Untuk menyediakan lapangan kerja bagi penduduk, terutama dari sektor pertanian yang jumlahnya semakin banyak, sedangkan kesempatan kerja sangat terbatas; (b) Meningkatkan taraf hidup, dan seringkali juga; (c) Untuk memperbaiki situasi neraca pembayaran; (d) Untuk meningkatkan gengsi suatu bangsa sehingga kerapkali terdapat proyek yang bersifat mercusuar (dari segi ekonomis mungkin tidak menguntungkan, tetapi dapat membawa kebanggaan suatu negara). 


\section{Journal of Indonesian Applied Economics \\ Vol. 2 No.1 Mei 2008, 68-89}

\section{Industrialisasi dan Pengelompokkan Tenaga Kerja Berdasarkan Jenis Pekerjaan}

Perkembangan ekonomi secara kuantitatif adalah sama seperti fenomena kualitatif. Menurut ekonom murni, kata perkembangan ekonomi memiliki arti perubahan kuantitatif, dimana hal ini berarti kenaikan signifikan pada tingkat pertumbuhan pendapatan per kapita meski terdapat pertumbuhan populasi penduduk, dan ada tenaga kerja ataupun input lain yang penggunaannya bergeser dari sektor pertanian ke sektor lain yang memiliki produktifitas lebih tinggi (Kuznets, 1988 dalam Lim). Sedangkan menurut ahli ilmu sosial yang lebih tertarik pada issue-issue yang lebih luas, perkembangan ekonomi berarti pada perubahan sosial yang lebih kompleks, yang mungkin dilihat dari sisi kualitatif, kondisi ini melibatkan transformasi ekonomi nasional seperti perubahan pada hubungan antar individu, antar kelas, kelompok-kelompok politik, dan teknologi maupun perubahan pada institusi negara yang semula didominasi oleh sektor pertanian yang kemudian bergeser pada pabrik-pabrik yang lebih modern.

Industrialisasi pertama kali terjadi di Inggris. Negara tersebut adalah yang pertama kali lepas dari 'Zaman Kegelapan' dari feodalisme, melalui penerapan ilmu pengetahuan dan teknologi pada proses produksi ekonomi. Negara tersebut juga yang pertama kali berhasil menerapkan sistem pabrik modern pada tekstil, dengan menerapkan inovasi yang meningkatkan produksi melalui mekanisasi, pertumbuhan teknologi tersebut membuat pabrik-pabrik bisa memberikan upah yang lebih tinggi, dan menarik pekerja yang semula bekerja di pertanian ke sektor industri domestik, dan secara bertahap penggunaan teknologi juga diterapkan pada industri-industri selain yang bergerak di bidang tekstil (Cameron, 1989). Transformasi yang cepat di Inggris ini terjadi pada tahun $1760-1830$, yang sering disebut sebagai Revolusi Industri yang sesungguhnya.

Revolusi industri terjadi pada awal abad 19, yang biasa juga disebut sebagai Zaman Mesin. Sebelum terjadi revolusi industri, semua barang diproduksi menggunakan tangan (secara manual), sehingga tempat pengolahan tidak terlalu besar dan biasanya terletak dekat dengan rumah pemilik usaha. Meskipun kuantitas produk yang dihasilkan relatif sedikit karena jumlah pekerja yang sedikit, namun terjadi hubungan; ikatan emosional (baik ataupun buruk) yang erat antara pekerja dengan pemilik usaha.

Pada masa ini, penemuan-penemuan baru yang penting dalam sejarah banyak ditemukan. Pada masa Renaissance, penggunaan bubuk mesiu meluas, mesin cetak ditemukan, dan pengolahan berbagai bahan. Mesin tangan sederhana menjadi lebih efisien. Pada tahun 1769, James Watt menemukan mesin uap, dan dengan adanya mesin ini daya mesin menjadi tidak tergantung kepada pengoperasian langsung oleh tangan. Metode ini diterapkan pada tempat kerja, dan terjadi peningkatan produksi barang. Dengan peningkatan produksi, maka kegiatan perdagangan juga tumbuh, yang diikuti dengan perpindahan tempat usaha (pabrik) ke lokasi yang jauh dari rumah pemilik usaha, sehingga jarak antara pemilik dan pekerja menjadi lebar.

Dengan adanya mesin yang digerakkan dengan 'tenaga independen' maka dimulailah suatu zaman; masa baru. Penemuan mesin industri menimbulkan terjadinya 'demam' perkembangan kegiatan; kecepatan produksi menyerap perhatian di bidang manajemen industri, dan pengulangan proses menggantikan keaneka ragaman pekerjaan tangan perorangan. Setiap mesin mempunyai tugasnya sendiri, dan setiap wanita, pria, atau bahkan anak-anak mempunyai mesinnya sendiri. Pabrik-pabrik mengalami perluasan dan jumlah pekerja bertambah banyak. Pabrik menjadi seperti magnet yang menarik semakin banyak permukiman pekerja, sekolah, dan toko-toko disekitarnya. Dengan adanya alat baru, jumlah pekerja mengalami peningkatan, sehingga terjadilah apa yang disebut sebagai Produksi Masal yang memungkinkan seseorang memiliki barang lebih banyak dibandingkan sebelumnya, hal ini karena jumlah produksi barang menjadi lebih banyak jika dibandingkan jumlah yang diproduksi secara manual.

Semenjak Inggris menemukan 'modernisasi', industrialisasi telah memiliki arti sebagai transformasi ekonomi nasional yang hampir sama artinya dengan meniru pemikiran dari Inggris (Coleman, 1966). Apakah yang menjadikan pengalaman Inggris ini istimewa? Faktor-faktor apa sajakah yang memberikan kontribusi pada kejayaannya sebagai negara industri pertama? Meski sulit untuk menemukan satu faktor utama, maka akan diprioritaskan pada beberapa variabel penjelas. Beberapa 


\section{Proses Industrialisasi di Indonesia}

Damayanthi

pandangan ditekankan pada struktur sosial-politik Inggris sebagai penyebab ‘tinggal landas' utama negara ini. Sebagian memfokuskan pada eksistensi tradisi Standestaat (pembagian kekuasaan antara raja, bangsawan penguasa wilayah, dan kota) yang dikombinasikan dengan rasionalisasi hukum dan agama di Inggris. Faktor-faktor ini melihat pada kegunaan dari kekuatan pemerintah secara acak, yang melindungi kota yang membentuk pasar dan rasionalitas ekonomi, yang pada akhirnya menuju pada pembentukan hubungan ekonomi kapitalis (Chirot, 1985).

Pandangan lain melihat pada komersialisasi pertanian dan diikuti dengan peningkatan kelompok Borjuis Liberal di Inggris, yang menganut sistem yang sangat kontras dengan sistem feodal sektor pertanian sebelumnya. Juga ada pandangan yang melihat dari sisi teknologi dan memberi penekanan pada 'Kluster Inovasi' (Deane, 1979). Dan yang terakhir, adanya beberapa penekanan dari pertumbuhan tiba-tiba pada permintaan, baik dari dalam negeri maupun luar negeri. Namun, belum satupun dari pendapat tersebut memberikan penjelasan secara umum dan teoritis. Dimana dari pendapat-pendapat tersebut dapat disimpulkan bahwa Inggris bisa mencapainya karena negara tersebut telah memiliki keadaan yang mendukung dan sesuai dengan persyaratan untuk itu sebelum negara lain bisa mencapainya (Higgins, 1968).

Dengan mengumpulkan pandangan-pandangan yang berbeda tersebut, mungkin yang bisa menjelaskan kesuksesan, dan bagaimana pengalaman Inggris tersebut bisa menyebar secara luas di seluruh dunia, adalah yang dikemukakan dan dikembangkan oleh Adam Smith. Pada tahun 1776, Adam Smith mengemukakan teorinya tentang kapitalisme Laissez-faire dalam bukunya yang berjudul The Wealth Of Nation, dan masih berpengaruh pada saat ini. Jumlah pekerja meningkat dengan sangat cepat dibandingkan jumlah pemilik usaha, yang melatar belakangi pembentukan Serikat Pekerja, yang berbeda dengan perserikatan tukang dan majikan yang terbentuk pada abad pertengahan.

Inti dari teori Smith pada industrialisasi adalah ide dimana peningkatan produktifitas bergantung pada peningkatan spesialisasi jenis produk ataupun kegunaan input-input tertentu. Smith menyatakan bahwa efek dari pengelompokkan tenaga kerja telah menghasilkan perbaikan terbesar dan terbaik pada produktifitas tenaga kerja. Dari penelitiannya terhadap pabrik pembuat pin, Smith menemukan bahwa tiap pekerja yang memiliki tugas tertentu yang spesifik pada proses pembuatan, pada akhirnya menghasilkan produksi pin yang lebih banyak daripada seorang pekerja yang mengerjakan proses pembuatan pin secara keseluruhan. Smith membagi karakteristi produktifitas dari pekerja yang tugasnya sudah dispesialisasikan pada tiga kondisi berikut: Perbaikan kemampuan (misalnya, pekerja dapat berkonsentrasi pada tugas tertentu dan hal ini akan meningkatkan kemampuannya), Penghematan waktu (yang biasanya banyak dihabiskan pada perubahan prosedur dari pekerjaan satu ke pekerjaan lainnya), dan Penggunaan mesin oleh pekerja (Smith, 1776/1976). Pengelompokkan tenaga kerja berdasarkan jenis pekerjaannya ini memberikan perbedaan besar jika dibandingkan dengan masa sebelumnya.

Pendapat Smith mengenai hubungan antara pembagian tugas tenaga kerja dan produktifitas secara lebih lanjut dijelaskan oleh Karl Marx. Marx menggunakan pendapat Smith mengenai pembagian tugas dengan pendapat mengenai fungsi mesin. Untuk Marx, spesialisasi tugas pekerja manusia sangatlah penting karena hal tersebut akan menuju pada pengenalan mesin otomatis yang hanya bisa digunakan pada proses tertentu. Marx berpikir jika satu tugas dapat dianalisa pada tindakan dasar; basisnya maka akan mungkin untuk membuat alat yang dapat melakukan tindakan tersebut secara otomatis. Sebagai satu langkah menuju proses industri secara mekanis, maka tahapantahapannya harus terorganisir sehingga bisa tetap berjalan meski menerapkan penggunaan mesin yang baru.

Bagi Smith dan Marx, penyebab transformasi dari pertanian yang feodal ke dunia industri yang kapitalis adalah penyebaran dari pembagian kerja secara spesifik yang meningkatkan produktifitas. Lebih jauh, tanpa memasukkan perbedaan pada cara pandang mereka dari segi politik, baik Smith maupun Marx percaya bahwa perbaikan ekonomi akan membentuk institusi politik baru berdasarkan persyaratan yang dibutuhkan oleh peningkatan efisiensi. Disini kita melihat pandangan klasik dari Teori Industrialisasi Secara Konvergen. 


\section{Journal of Indonesian Applied Economics \\ Vol. 2 No.1 Mei 2008, 68-89}

Inti dari teori ini adalah susunan institusi dari sebuah negara yang memfokuskan pada perkembangan akan menjadi konvergen secara perlahan-lahan, karena industrialisasi bergantung pada difusi dari produksi teknologi, dan peranan kuat dari teknologi dalam membentuk kemampuan, pembagian kerja tenaga kerja, dan struktur kekuasaan (Lincoln, 1990). Prinsip dari penerapan secara universal terhadap semua pihak dalam pasar ekonomi adalah adanya pembagian kerja, spesialisasi, dan teknologi, karena pihak-pihak tersebut mencari efisiensi. Menurut pandangan konvergen, selanjutnya akan selalu ada metode dan cara yang lebih baik dari metode-metode maupun cara-cara produksi sebelumnya. Lebih lanjut, teori ini memprediksikan industrialisasi secara linier, dari kerajinan ke pabrik, yang berujung pada produksi masal. Selanjutnya teori ini berpendapat akan pentingnya dari kemajuan masyarakat industri akan semakin mengurangi perbedaan pada organisasi sosial antara pelaku industrialisasi lama dan baru, yang memimpin difusi dari organisasi industri pada backward zones. Sehingga, jika ada pertanyaan bagaimana negara yang tertinggal dapat menyusul, maka jawabannya adalah 'Duplikat'. Sejauh ini telah ditunjukkan bahwa model kasar; awal dari industrialisasi adalah evolusioner atau linier pada karakternya, dan menitik beratkan pada ide bahwa tahap dari produksi pabrik berskala besar adalah menggambarkan karakteristik dari industrialisasi.

\section{B. INDUSTRIALISASI DI ASIA}

Literatur mengenai industrialisasi di Asia, khususnya di Asia Timur, banyak difokuskan pada hubungan antara kebijakan dan outcomes ekonomi. Dari sudut pandang intelektual, sebagian besar perdebatan terjadi antara penjelasan pasar neoklasik dan perkembangan negara. Tujuan utama dari bagian ini adalah untuk menghubungkan model tersebut dengan teori konfensional dari industrialisasi yang telah dijelaskan diatas. Disini, akan digambarkan bahwa dua pendekatan utama pada industrialisasi di Asia masih terikat dengan paradigma industrialisasi di negara Barat.

\section{Perspektif Atas Pasar}

Salah satu pendekatan yang digunakan untuk memahami Ekonomi Politik di Asia adalah dengan melihat pasar sebagai penyebab utama perluasan perekonomian suatu negara atau wilayah. Menurut pada teori ekonomi Neoklasik, pendekatan ini memasukkan pasar sebagai alat yang paling efisien dan paling kuat dari alokasi sumber daya untuk memaksimalkan produksi. Keberhasilan dari kawasan Asia Timur menurut pendekatan ini adalah bukti yang kuat atas prinsip pasar bebas.

Dalam perspektif teori ekonomi, pasar adalah salah satu mekanisme yang bisa dijalankan oleh manusia dalam mengatasi problem ekonomi: produksi, konsumsi dan distribusi. Heilbroner (1972) menyebutkan, alternatif selain mekanisme pasar yang ada dalam sejarah peradaban adalah tradisi (custom) dan ekonomi terpimpin (command economics). Keduanya serta mekanisme pasar terbukti mampu mengatasi persoalan konsumsi dan produksi. Tetapi masing-masing juga memiliki kelemahan. Masalah dalam tradisi adalah ia bersifat statis dan cenderung tidak adaptif terhadap tuntutan perubahan.

Ekonomi terpimpin dalam sejarah terbukti mampu menciptakan kesejahteraan sekaligus kemajuan peradaban. Namun ketika masyarakat menjadi semakin besar, sistem ini menghadapi limitasi karena sumber daya yang dibutuhkan untuk mempertahankan power juga makin besar. Mekanisme pasar menawarkan solusi atas problem yang dihadapi oleh ekonomi terpimpin. Mekanisme pasar tidak membutuhkan kekuasaan yang besar untuk menentukan apa yang harus dikonsumsi dan diproduksi. Sebaliknya, tiap individu dibebaskan untuk memilih sendiri apa yang ia butuhkan dan bagaimana memenuhinya. Selanjutnya, kata Adam Smith, serahkan pada invisible hand, dan "dunia akan teratur dengan sendirinya". Dasar dari keputusan para pelaku ekonomi adalah voluntary, sehingga otoritas dan komando tidak lagi terlalu diperlukan. Biaya untuk mempertahankan otoritas pun diminimalkan.

Dari kacamata ekonomi pasar, peranan pemerintah sebaiknya ditekan seminimal mungkin. Pembenaran atas dibolehkannya pemerintah masuk sebagai pelaku pasar (intervensi) hanyalah jika pasar tidak dalam keadaan sempurna, dalam arti ada kondisi-kondisi yang menghalangi kompetisi 
yang adil terjadi. Dalam buku teks, kondisi-kondisi tersebut dikenal dengan istilah market failure. Kondisi market failure antara lain: keberadaan barang publik, eksternalitas (termasuk pencemaran dan kerusakan lingkungan), informasi yang tidak simetris, biaya transaksi, kepastian institusional serta masalah dalam distribusi. Dalam bahasa yang lebih singkat, masuknya pemerintah adalah untuk menjamin fairness; keadilan. Sekalipun kondisi market failure terjadi, tetap ada sejumlah pertimbangan apakah intervensi perlu dilakukan, yaitu kemungkinan terjadinya government failure, yang jika terjadi akan menimbulkan 'kerusakan' lebih besar dibandingkan market failure (Perdana, 2001).

Teori Neoklasik menyatakan bahwa alasan mengapa industri manufaktur di Asia Timur dapat tumbuh dengan cepat adalah karena ekonomi mereka yang relatif bebas untuk melakukan distorsi modal, tenaga kerja, teknologi, dan faktor-faktor lain yang menentukan mekanisme pasar. Secara spesifik, pandangan neoklasik mengatakan bahwa pemerintah di negara-negara Asia Timur-tidak seperti karakteristik negara berkembang lainnya- tidak melakukan intervensi pada pasar, ataupun jika ada intervensi adalah untuk mengoreksi pasar. Sehingga negara-negara tersebut melakukan industrialisasi dengan menggunakan prinsip 'Menerapkan Harga Yang Sesuai; Tepat' (dimana penawaran dan permintaan yang menentukan besarnya harga) dan secara tipikal menerapkan upah yang rendah untuk memperoleh keuntungan komparatif pada industri padat karya. Hughes menyimpulkan posisi neoklasik sebagai berikut:

"Sekali barang publik digunakan untuk sarana koreksi, pasar akan melakukan tugasnya sebagai alokasi sumberdaya dengan baik... Yang telah dibuktikan di Asia Timur... yang merupakan prinsip utama dari ekonomi neoklasik" (Hughes, 1988)

Aliran neoklasik berpendapat bahwa terdapat korelasi positif antara kebijakan yang memprioritaskan ekspor dan pertumbuhan yang cepat di kawasan ini. Menurut pandangan neoklasik, perkembangan; pertumbuhan suatu negara akan lebih baik jika menggunakan kebijakan yang export oriented jika dibandingkan dengan menggunakan kebijakan substitusi impor, karena alasan-alasan berikut:

- Karena pertumbuhan diperoleh dari ekpansi dari produsen-produsen yang efisien, perusahaan yang bersaing pada pasar internasional akan lebih maju dibandingkan hanya berharap pada proteksi pasar domestik (Kuznets, 1988).

- Karena pasar ekpor lebih luas dibandingkan pasar domestik, produsen-produsen di negara berkembang dapat memperoleh keuntungan pada skala ekonomi, dengan menggunakan fasilitas industri menufaktur pada jumlah yang efisien (Kuznets, 1988; Krueger, 1985).

- Karena negara-negara terbelakang secara definisi memiliki penawaran besar pada tenaga kerja yang berkemampuan minimum, strategi export oriented menyebabkan negara-negara tersebut menerima keuntungan dari pembagian tugas tenaga kerja melalui pertukaran antara komoditas padat karya untuk barang-barang padat modal (Krueger, 1985).

Pertumbuhan orientasi ekspor, berkembang sejak tahun '60-an merupakan titik balik bagi pertumbuhan secara cepat di banyak negara. Penerapannya di suatu negara membutuhkan kebijakan makroekonomi yang stabil, kebijakan tingkat pertukaran yang ralistis, dan liberalisasi perdagangan yang selektif-merupakan hal yang menyebabkan negara mask dalam kompetisi pasar dunia- merupakan tanda bagi perusahaan-perusahaan domestik akan keuntungan relatif mereka dan mengijinkan mereka untuk mengekploitasinya melalui kebijakan ekspor, industri-industri padat karya seperti tekstil, sepatu, dan suku cadang elektronik, dll. Penerapan kebijakan harga yang sesuai memberikan pengaruh positif pada mekanisme kekuatan pasar. Yang menghasilkan tingkat pertumbuhan sebesar dua digit pada tiga dekade terakhir.

\section{Kritik Terhadap Mekanisme Pasar}

Pertama, dengan berpendapat bahwa kebijakan yang berorientasi ekspor lebih berperan pada perekonomian negara dibandingkan kebijakan substitusi impor, penganut pandangan neoklasik dari wilayah ini menghasilkan asumsi yang sama yang diperkuat oleh para penulis aliran klasik sebelumnya pada industrialisasi negara Barat. Penganut aliran neoklasik mengulangi ide bahwa 


\section{Journal of Indonesian Applied Economics \\ Vol. 2 No.1 Mei 2008, 68-89}

industrialisasi merupakan usaha untuk memperoleh skala ekonomi melalui spesialisasi dan pembagian tugas tenaga kerja. Kedua, secara implisit pada Teori Neoklasik percaya bahwa terdapat tahapan tertentu pada perkembangan yang tidak dapat dilewati untuk tujuan akselerasi proses pertumbuhan.

Menurut tradisi pandangan ekonomi klasik dan neoklasik, mekanisme pasar mengimplikasikan adanya persaingan terbuka antara pencari keuntungan. Jika persaingan berlangsung terbuka, keuntungan yang tiap pelaku secara individu hanya akan terjadi dalam tingkat minimal. Sebaliknya, tanpa adanya persaingan, tiap-tiap individu bisa memperoleh keuntungan yang besar (supernormal profit) (Perdana, 2001).

Contohnya, Krause percaya bahwa pada tiap tahapan industrialisasi pada kawasan ini memiliki tujuan: Tahap awal dari industri padat karya yang berdasarkan surplus tenaga kerja sangat diperlukan untuk mencapai full employment, yang menghasilkan keuntungan sosial dalam distribusi pendapatan dan mengurangi kemiskinan. Tahap berikutnya ditandai dengan berkurangnya surplus tenaga kerja, pelatihan pada pengusaha domestik, dan mengijinkan mereka untuk mengumpulkan modal pribadi untuk meningkatkan investasi dengan skala yang lebih besar (Krause, 1985).

Berdasarkan pemikiran Krause, kita dapat berpendapat bahwa Neoklasik digunakan untuk mengasumsikan konfergensi; penggabungan pada aktivitas ekonomi. Lebih jauh, pandangan neoklasik memprediksikan bahwa industri modern kawasan ini tidak memiliki tempat bagi perusahaan kecil, dan jalur pertumbuhan ada pada berkurangnya dukungan terhadap perusahaan korporasi, yang ditandai spesialisasi dan produksi masal. Barret dan Chen (1987), memprediksikan bahwa 'institusi ekonomi, politik, dan sosial dari negara-negara yang memiliki orientasi ekspor akan semakin mapan dan struktur industrinya akan semakin berpadu dengan negara-negara maju'.

\section{Developmental State Theories}

Bukan hanya aliran neoklasik yang menerima ide konfergensi ini. Teori negara maju (atau teori negara adidaya) mengungkapkan teori lain dari konfergensi ini pada karyanya dengan pendapatnya mengenai 'Industrialisasi Terkini'. Teori ini dikembangkan dari neoklasik dengan mengutamakan Late Industrialization sebagai paradigma baru, dengan artian pada operasional dari mekanisme pasar dan peranan dari pemerintah negara. Dalam proses pembuatan pandangan tersebut, mereka banyak mengadopsi pandangan dari Alexander Gerschenkron yang meneliti usaha negara-negara untuk mengejar ketertinggalannya; catching up sebagai proses revolusioner yang eruptif.

Gershenkron tidak setuju terhadap adanya pandangan bahwa 'proses industrialisasi terulang dari negara satu ke negara lain melalui alur Pentametric dan mendemonstrasikan kebalikannya, bagaimana pendatang baru seperti Jerman dan Rusia berbeda secara fundamental berbeda dari generasi pertama negara-negara industri, berdasarkan intensitas usaha catching up, ia mengemukakan logika berikut:

- Negara industri baru, secara definisi kekurangan beberapa elemen kunci; syarat-syarat tertentu yang dikarakterisasikan oleh negara industri pertama (syarat tersebut adalah institusi kapitalis seperti borjuis endogen, pasar bebas, kewirausahaan, dll).

- Negara industri baru, bagaimanapun, dapat memperbaiki posisi mereka atau memberi kompensasi untuk syarat yang kurang tersebut melalui adaptasi politik dan institusi. Metode atas kompensasi ini dapat berbeda-beda, tergantung dari negara yang bersangkutan, terutama tergantung pada variabel eksogen -'waktu' penerapan proses industrialisasi.

- Semakin terbelakang perekonomian sebuah negara, semakin besar peranan pemerintah dalam proses industrialisasi, melaui faktor institusi yang didesain untuk meningkatkan supply modal pada industri yang dikembangkan, sebagai tambahan, adalah mengurangi desentralisasi dan informasi yang lebih baik sebagai aturan kewirausahaan.

Singkatnya, semakin lambat waktu perkembangannya, semua hal akan menjadi sama, maka peranan dari negara dalam mengatur perekonomian akan semakin besar. 


\section{Kritik Terhadap Developmental State Theories}

Developmental State Theories dan Gerschenkeron berhasil menunjukkan bahwa negara industri baru tidak hanya sebagai perluasan dari kapitalisme negara, dan terdapat lebih dari satu cara untuk berkembang. Sebagai faktanya, apa yang membuat teori ini meyakinkan dan menarik adalah adanya implikasi bahwa pendatang baru yang menerapkan politik industrialisasi yang tepat (atau jika mereka merencanakannya secara rasional), dapat memperoleh keuntungan dari keterlambatan tersebut karena negara mampu untuk mengatur strategi industrialisasinya dan tidak sebagai obyek dalam ekonomi dunia melainkan melalui kapasitas dan struktur domestik negara tersebut (Haggard, 1986). Dan negara pendatang baru dapat belajar dari pengalaman pendahulunya dan mengadopsi bentuk produksi yang paling efisien dan modern.

Amsden juga menunjukkan bahwa negara industri baru melalui stigma learning by doing, dapat menciptakan 'institusi modern' seperti intervensi pemerintah, dan industrialisasi skala besar (Amsden, 1989). Namun, gambaran dari negara yang mengisi kebijakan perkembangan jangka panjang menimbulkan beberapa pertanyaan. Pertama, literatur menganggap negara sebagai agen ekonomi dengan mengasumsikan bahwa fungsi dari negara-negara di kawasan Asia Timur adalah untuk membuat pilihan-pilihan kebijakan strategis yang ditujukan untuk proses industrialisasi. Dengan bertindak demikian, developmental state theories ditujukan untuk menghubungkan cara kerja rasionalitas di negara dengan jenis rasionalitas yang dilakukan pada organisasi swasta pada hubungan dalam pasar. Untuk organisasi swasta yang beroperasi dalam pasar (misalnya perusahaan bisnis), kriteria untuk efisiensi ditunjukkan oleh keuntungan dan pendapatan marjinal. Bagaimanapun, pada kasus sebuah negara, kriteria efisiensi yaitu rasional pada hubungan pasar tidak terjadi, sehingga akan sulit untuk menjelaskan arti dari clear cut pada efisiensi. Dengan mengalihkan peranan pemerintah pada pelaku ekonomi. Developmental state theories hanya dapat diterapkan pada analisa tertentu yang ingin mengetahui mengapa negara dapat membuat versinya sendiri tentang "rencana rasionalisasi". Singkatnya, teori ini hampir sama dengan teori neoklasik, yaitu menganggap negara sebagai agen non politik. Kondisi ini menjadi dasar dari kritik berikutnya.

Kedua, pada teori ini politik digunakan sebagai alat yang digunakan negara industri baru untuk menerapkan spesialisasi. Menurut teori ini, negara berperan dalam merencanakan dan mengkoordinasikan aktifitas ekonomi karena pasar kompetitif masih belum berkembang pada negara industri baru ini. disini politik menjadi bagian dari kebijakan, dan politik diperlakukan sebagai faktor eksternal. Dengan kata lain, teori ini melihat politik sebagai alat untuk mempercepat proses industrialisasi, yang pada akhirnya dapat dilihat melalui keberadaan kondisi berikut: industrialisasi berskala besar dengan keberadaan intervensi pemerintah.

\section{POLITIK PADAINDUSTRIALISASI}

Pada bagian ini, akan digambarkan bagaimana industrialisasi dipahami sebagai proses politik yang esensial, dimana pada bagian ini akan dijelaskan mengenai sebuah Struktur Industri.

\section{Industrial Order}

Industrial Order adalah kumpulan dari ide, sistem, peraturan; undang-undang, dan institusi yang mengatur serta menentukan outline dari cara-cara yang digunakan untuk memproduksi barang, dan administrasinya (Herrigel, 1990). Sering diciptakan ketika terjadi gangguan pada organisasi dan terjadi strategi yang ambigu dari formasi industri. Industrial Order berisi aturan dasar untuk cara transaksi yang dapat diterapkan yang akan memberikan peningkatan pada mekanisme perusahaan dan pemerintah, seperti pasar dan hirarkhi. Singkatnya, industrial order adalah pola pikir yang disusun secara politik dan sosial yang menciptakan latar belakang yang berisi daftar spesifik yang muncul dari mekanisme pemerintahan (pasar, hirarkhi, atau jaringan) (Herrigel, 1994).

Industrialisasi tidak bisa secara sederhana dianalisa sebagai usaha untuk meraih efisiensi. Dengan adanya halangan berupa endowment, maka proses tersebut bisa menjadi proses produksi atau proses sosial. Hal seperti itu terjadi dalam Pandangan Neoklasik. Selain itu, perkembangan 


\section{Journal of Indonesian Applied Economics Vol. 2 No.1 Mei 2008, 68-89}

ekonomi melalui industrialisasi adalah issue sosial politik yang didalamnya terdapat konflik dan kompromi, juga dominasi dan subordinasi dari kekuatan yang berbeda baik didalam maupun diluar aparatur negara. Ini merupakan proses dari usaha oleh pihak-pihak yang terlibat-apakah mereka adalah sebuah negara atau wilayah bagian, perusahaan, atauh bahkan pekerja- yang menyusun sekumpulan solusi untuk menyelesaikan masalah yang harus dihadapi oleh lingkungan industri mereka. Jika perkembangan terjadi secara singkat; cepat, maka issue itu disebut sebagai Alokasi Industri (Piore dan Sabel, 1984), dan hasil atau hubungan institusional disebut Industrial Order.

Sekali industrial order dibuat, maka struktur dasar dari 'order' ini berarti kestabilan atau telah terinstitusionalisasi melalui kepentingan dan ide-ide yang membantu menjaga reproduksinya. Hampir sama dengan konsep Gramscian pada hegemoni dimana ideologi yang mendominasi pada beberapa nilai adalah tidak dapat dipertanyakan dan diterima sebagai pandangan umum, maka sekali ideologi industrialisasi mendominasi, maka akan menjadi sebuah paradigma atau pandangan baru dari efisiensi produktifitas, kumpulan ide, dan sistem bisa menjadi yang paling benar; baik dimana persaingan ide menjadi tidak mungkin. Keberadaan dari jenis-jenis pabrik yang berbeda adalah contoh yang baik. Bahkan saat ini, industri pra pabrik; prefactory (konstruksi, pertanian, dll) masih banyak menggunakan tenaga kerja yang tidak dibayar dan pekerja dari anggota keluarga itu sendiri yang memegang peranan besar, dibandingkan dengan industri yang ada setelah revolusi industri (menggunakan mesin) dimana otoritas lebih bertingkat-tingkat (secara hirarkhi), non personal, dan membutuhkan birokrasi. Menurut Stinchcomb, 1965 organisasi pada pabrik yang dibentuk pada satu masa struktur sosialnya akan berbeda secara tipikal dengan yang terbentuk di masa yang lain, karena organisasi tersebut harus memiliki dasar utama pada tujuannya dengan alat; sarana yang dikembangkan pada waktu tersebut. Sekali organisasi terbentuk, mereka akan menjaga strukturnya, bukan karena mereka yang paling efisien secara ekonomi, namun mungkin karena mereka tetap merupakan bentuk yang efisien untuk mencapai tujuan yang ditentukan dan sesuai dengan ideologi yang digunakan untuk menjaga reproduksi dan strukturnya. Industrial order pada arti ini adalah sejenis pengertian secara konstitusional pada lingkup produksi (Herrigel, 1994).

\section{Pendekatan Institusional}

Akhir-akhir ini, pandangan dari ahli institusional baru, mengkombinasikan variabel perkembangan teknologi, negara, pasar, dan budaya untuk menggambarkan prinsip organisasi sebuah kelompok bisnis (Hamilton dan Biggart, 1991). Ide dasarnya adalah bahwa organisasi menggambarkan isomorphism pada lingkungan institusi. Yaitu, organisasi akan memiliki struktur yang semakin sama pada saat mereka bereaksi pada aturan dan tekanan normatif dari institusi, atau mereka akan meniru struktur yang digunakan oleh organisasi yang berhasil menghadapi masalah tersebut.

Masalah pada analisa institusi ini adalah pendekatan yang digunakan berdasarkan nilai, yang mengharuskan adanya pengukuran secara spesifik yang sama seperti analisa masalah. Jelasnya, institusi dan nilai yang disebutkan diatas bisa merupakan komponen utama yang memperngaruhi budaya; kultur bisnis di sebuah negara. Masalahnya, institusi dan nilai tersebut mungkin akan sama pada tiap negara. Contohnya, orang dapat dengan mudah berpendapat bahwa sistem manejerial Amerika juga mempengaruhi sistim bisnis Taiwan, sementara keinginan untuk menjadi pemimpin bisnis keluarga sangat kuat sama seperti yang terjadi di Korea. Untuk menghitung tingkat pengaruh faktor budaya sangatlah sulit.

Masalah kedua pada pendekatan ini adalah perlakuan pada budaya sebagai determinan bebas dari kebiasaan. Jika nilai tertentu memiliki hubungan dengan organisasi yang berbeda, maka salah satunya membutuhkan penjelasan atas sumber dari nilai-nilai tersebut. Apakah kelompok bisnis akan menerapkan tindakan yang diusulkan atau tidak, tergantung pada seberapa besar hambatan pada situasi ekonomi politik. Terakhir, pendekatan ini berkaitan dengan banyak variabel. Lincoln, 1990 berpendapat bahwa teori ini secara unik berhubungan dengan prinsip akuntansi karena teori ini memberi perhatian secara eksplisit pada peranan dari budaya, hukum, dan pengaruh politik dalam penyusunan strategi dan bentuk organisasi. 


\section{POLITIKSEBAGAI VARIABELBEBAS}

\section{Diluar Voluntarisme}

Pandangan bahwa negara 'membentuk' sektor swasta, bukanlah hal baru. Faktanya, pandangan ini ada pada inti dari developmental state theories (Gold, 1986). Dalam literatur tersebut secara implisit terdapat pendapat voluntaristic yang berpendapat bahwa industrialisasi pada sebuah negara tergantung pada keputusan pemerintah, dengan tetap mempertanyakan apakah negara menganalisa konteks politik dimana negara melaksanakan fungsinya. Beberapa voluntarisme secara erat berkaitan dengan konsep sebuah negara yang diekspresikan oleh visi sebuah negara.

Teori ini telah mengurangi peranan pemerintah dengan menjadikannya pelaku ekonomi, dan menganalisa kebijakan pemerintah dengan kriteria tunggal berupa efisiensi yang maksimal pada produksi barang dan jasa untuk pasar dan masyarakat. Kita tahu bahwa efisiensi tidak pernah menjadi satu-satunya faktor yang dipertimbangkan dalam kebijakan suatu negara. Rueschemeyer berpendapat bahwa efisiensi adalah konsep yang tidak berarti, kecuali ada nilai sepesifik dari apa yang diperoleh dan apa yang dikorbankan. Ini merupakan struktur preferensi individu -kebutuhan dan keinginan mereka yang disusun berdasarkan prioritas- yang menentukan nilai perolehan dan kehilangan (gain and losses), dimana struktur tersebut sangat bermacam-macam, tidak hanya lintas budaya namun juga lintas kelompok dan kelas secara antagonis terlibat dalam proyek yang sama pada produksi dan kehidupan sosial. Apa yang efisien menurut satu kriteria, adalah inefisien bagi kriteria lain.

Jika kita menerima pandangan bahwa intervensi pemerintah pada ekonomi seluruhnya tidak berdasarkan pada kalkulasi secara rasional dari apa yang berguna bagi sistem secara keseluruhan, maka pertanyaannya adalah apa yang menjadi motif dari kontribusi tersebut. Dimana, keinginan dan reaksi dari penguasa harus dimulai dengan menganalisa kebijakan ekonomi negara. Yang mana sebagian besar penguasa melakukan intervensi perekonomian untuk alasan politik tertentu. Pendapat diatas berdasarkan asumsi yang masuk akal, bahwa pemimpin politik tidak akan membuat pilihan yang menyebabkan terjadinya kondisi yang lebih jelek dari status quo, dimana sebagian besar intervensi dilakukan untuk mengatasi masalah ketidak pastian politik yang dihadapi oleh rezim tersebut.

\section{Krisis Politik dan Pilihan Strategi}

Hirscman, 1963 menyatakan, hanya saat terjadi krisis politik, pemerintah mau memperhatikan masalah-masalah berikut: perubahan dari kondisi rendahnya pengetahuan, kurang motivasi, dan kurangnya perhatian. Periode krisis politik akan menghasilkan pola perubahan tertentu, yang mirip dengan konsep masa-masa penting sebuah pemerintahan; critical juncture.

Masa-masa tersebut merupakan periode terjadinya perubahan signifikan yang secara tipikal dialami dengan cara yang berbeda pada masing-masing negara dan menghasilkan kultur yang berbeda pula. Ini merupakan periode ketika aturan yang ada terkait dengan kegagalan pemerintah sehingga mungkin terjadi perubahan institusi. Masa tersebut juga dapat disebut dalam pandangan pemerintah sebagai ketidak pastian yang tinggi (Silberman, 1993), didefinisikan disini sebagai kondisi dimana seseorang; pemerintah tidak bisa memastikan kemungkinan dari suatu peristiwa, sehingga tidak bisa mengambil langkah untuk menghadapi dampak yang mungkin ditimbulkan oleh masalah tersebut (North, 1990).

Kapan pemerintah mengalami periode tersebut? Selain perbedaan pada obyek penekanan, ahli sosial setuju bahwa pemimpin negara mengalaminya pada saat terjadi krisis kepemimpinan. Pertanyaan mengapa rezim tersebut harus berkuasa, merupakan pertanyaan yang paling sering ditanyakan kepada pemerintah. Pada kondisi ini kepemimpinan yang baru akan menyatakan bahwa rezim sebelumnya gagal atau inefisien dan berusaha untuk menciptakan peraturan baru. Seperti pada proses legitimasi, dan dari pandangan pemimpin politik, prosesnya termasuk pembuatan pilihan strategis dimana mereka percaya akan mengurangi kondisi ketidak pastian politik.

Untuk memperoleh dan menjaga kekuasaan, sistem politik harus menciptakan dan menjaga kepercayaan bahwa institusi politik yang ada saat ini adalah yang terbaik bagi masyarakat. Terdapat dua metode dimana kondisi ini bisa tercapai: Secara institusi dan instrumental legacies. Dengan cara 


\section{Journal of Indonesian Applied Economics Vol. 2 No.1 Mei 2008, 68-89}

institusional, kekuasaan ditekankan pada proses perolehan kekuasaan yang dipeoleh melalui institusi yang ada, yang dapat diterima dan sesuai. Keuntungan dari cara ini diturunkan dari adanya fakta bahwa kekuasaan sangat terkait dengan aturan yang berlaku, dimana penguasa dengan bebas menentukan siapa saja yang duduk dan berperan dalam politik dan tujuan apa yang akan dicapai melalui aturan pemilihan umum.

Selain besarnya pengaruh dari kekuasaan institusi, dua kondisi tersebut membuat pilihan ini menjadi tameng pada masa ketidakpastian politik. Dibawah ketidakpastian politik, pemimpin yang baru tidak memiliki institusi; lembaga yang menjadi 'pegangan' karena mereka memperoleh kekuasaan dengan menyatakan bahwa rezim sebelumnya tidak efisien dan mereka juga dibatasi oleh rasionalitas. Jika pimpinan politik menganut aliran neoklasik, dimana semua pelakunya adalah rasional dan berorientasi pada masa mendatang, maka mereka dapat mengumpulkan dengan mudah informasi yang relefan mengenai kondisi yang mungkin terjadi, untuk menentukan keputusan. Bagaimanapun, dalam kenyataannya cara tersebut membutuhkan biaya mahal, informasi selalu tidak lengkap dan pembuat keputusan tidak bisa memperolehnya, dan tidak mampu untuk mengevaluasi informasi yang ada. Sehingga rasionalitas pengambilan keputusan sering dipengaruhi oleh faktor-faktor seperti ilmu pengetahuan, kemampuan individu, nilai, dan persepsi (Simon, 1976).

Pada masa ini, keputusan akan sering terhambat oleh waktu yang tidak tepat. Lebih lanjut, pengambil keputisan jarang memiliki kejelasan, konsistensi, ataupun tujuan tetap pada jangka panjang. Satu-satunya yang biasa terjadi pada kepemimpinan baru adalah terbentuknya ideologi tentang bagaimana kondisi yang seharusnya terjadi di masa mendatang.

Karena kekuasaan istitusional tidak bisa diperoleh dengan mudah, maka penguasa baru akan lebih memilih pilihan kedua, yaitu instrumental legitimacy atau bukti efektifitas. Lain dengan legitimasi institusi, legitimasi ini tidak membutuhkan campur tangan langsung dengan menggunakan hukum atau perintah politik secara absolut. Sebagai gantinya hal ini membutuhkan persetujuan, seperti yang ditekankan oleh Jackman, 1993 bahwa berbagai macam simbol dapat digunakan pada prosesnya. Relatif bebas dari hasil yang spesifik, legitimasi ini berperan sebagai subyek dari dukungan atas dampak yang terjadi, meski membutuhkan waktu yang lama dan menggunakan stigma tertentu, cara tersebut dapat berkembang menjadi kekuasaan secara institusi (Goldstein, 1988).

Legitimasi ini dapat diperoleh melalui perbaikan performa makro ekonomi (seperti pertumbuhan ekonomi atau stabilitas). Kondisi ini secara kolektif, tak terpisahkan, dan dialami oleh seluruh masyarakat. Bagaimanapun ada trik pada tipe ini: membutuhkan dukungan secara konstan melalui hasil yang nyata yang merupakan subyek untuk pada diminishing return. Sekali dilakukan, performa sebelumnya dibutuhkan untuk pengambilan keputusan dan performa yang lebih baik dibutuhkan pada tingkat yang sama dari efek kekuasaan tersebut. Kondisi ini akan membuat para pemimpin enggan untuk menemukan kebijakan alternatif jika mereka telah memperoleh formula yang bisa digunakan. Sebagai ringkasan, pada saat ketidakpastian politik menyebabkan suksesi kepemimpinan, para pemimpin yang dibatasi oleh rasionalitas, akan memilih strategi yang memiliki tujuan untuk mengurangi ketidakpastian politik tersebut. Pemilihan strategi ini dipilih untuk melegitimasi ketidakpastian dalam jangka pendek tersebut. Bagaimanapun, keputusan tersebut menetapkan arah pada perubahan tertentu, dimana pada jangka panjang menghasilkan konsekuensi; dampak yang tidak direncanakan.

\section{E. INDUSTRIALISASI DI INDONESIA}

Proses industrialisasi di Indonesia terbagi dalam berbagai tahapan, dimana pergeseran kepemimpinan nasional dari Presiden Soekarno ke Jenderal Soeharto pada tahun 1966 membuka cakrawala baru bagi Indonesia dalam bidang ekonomi dan politik (Weinstein, 1976). Pada saat itu, kondisi ekonomi Indonesia sangat parah dimana kondisi ini ditandai dengan tingginya tingkat inflasi yang mencapai ratusan persen per tahun serta tingkat pertumbuhan ekonomi yang sangat rendah (bahkan negatif), utang luar negeri yang menumpuk dan tidak bisa diangsur kembali dengan hasil ekspor yang nilainya hanya beberapa ratus dolar per tahun (Kuncoro, 2007). Akhir 1960-an sampai 
dekade 1970-an, industri tambang menjadi primadona dengan sebagian besar hasil eksploitasi dibawa ke luar negeri, baik barang dagangan maupun akumulasi keuntungannya.

Yustika, 2007 menjelaskan bahwa dalam operasionalisasinya yang paling tampak, setidaknya selama ini terdapat tiga pemikiran strategi industrialisasi yang berkembang di Indonesia, dimana ketiganya pernah diaplikasikan secara tersendiri ataupun bersama-sama, yaitu:

- Strategi industrialisasi yang mengembangkan industri-industri yang berspektrum luas (broadbased industry).

- Strategi industrialisasi yang mengutamakan industri-industri berteknologi canggih berbasis impor.

- Industri hasil pertanian (agroindustry) berbasis dalam negeri dan merupakan kelanjutan pembangunan pertanian (Saragih, 1998).

Seperti pada negara berkembang lainnya, proses industrialisasi di Indonesia ditopang sejumlah besar kebijakan yang sangat memproteksi pada bidang perdagangan dan industri termasuk didalamnya penggunaan bea masuk dengan prosentase nominal yang efektif, penggunaan non-tariff barriers, dan larangan total terhadap impor. Dengan pola pandang tersebut, sejak awal industrialisasi di Indonesia telah menempuh strategi substitusi impor sebagai alat membangun sektor industri, dimana strategi ini sarat dengan berbagai intervensi negara untuk melindungi kegiatan ekonomi nasional (Yustika, 2007).

Reformasi kebijakan terpenting yang dilakukan pada masa awal pemerintahan Presiden Soeharto adalah dibebaskannya sistem kontrol devisa, diberlakukannya kebijakan anggaran berimbang sebagai alat stabilitas ekonomi, dan dibukanya pintu bagi masuknya modal asing melalui UU Penanaman Modal Asing No. 1/1967, dan ditarik masuknya devisa yang dimiliki oleh penduduk Indonesia yang lari dan bermukim di luar negeri, melalui UU Penanaman Modal Dalam Negeri No.6/1966. stabilisasi dan liberalisasi ekonomi pada akhir tahun ' 60 -an ini merupakan titik awal bagi pembangunan ekonomi dan industri yang berkelanjutan di Indonesia.

Orientasi kebijakan ekonomi-politik Orde Baru bisa diibaratkan bergerak seperti ayunan pendulum. Hal inilah yang membuat sulitnya mengambil sebuah generalisasi yang kuat, terutama jika kita coba menyimpulkan paham atau 'ideologi' apa yang dianut. Pada kenyataannya, apa yang dianggap sebagai 'ideologi' yang melatarbelakangi sebuah kebijakan ekonomi sebenarnya tak lain dari sebuah pragmatisme. Hal ini juga diungkapkan secara skeptis oleh Robison (1986:109):

... kebijakan dipilih bukan karena yang terbaik, baik menurut pandangan obyektif maupun universal, namun karena kebijakan tersebut menjanjikan pertumbuhan sosial dan ekonomi yang bisa diterima oleh penguasa politik baru di Indonesia.

Senada dengan Robison, Hill (1997:305) juga mengatakan:

Adalah kesalahan dalam melihat perubahan rezim ditahun 1966 sebagai perubahan dari 'sosialis' ke 'kapitalis' atau rezim 'pasar bebas'. Saat itu masih terdapat penyalah gunaan kekuatan pasar, liberalisme ekonomi dan kepemilikan swasta (terutama etnis Cina) pada banyak sektor penting di Indonesia.

Untuk melihat secara lebih detail mengenai orientasi kebijakan pada masa tersebut, kita bisa meninjau karakteristik kebijakan ekonomi Orde Baru dalam sejumlah periode. Pembangunan yang dilakukan pada masa pemerintahan Orde Baru dapat diklasifikasikan dalam 4 fase besar (Hill, 1992). Pertama, menciptakan iklim yang baik untuk meningkatkan permintaan konsumen, meningkatkan pertumbuhan ekonomi yang cepat, dan memberikan kesempatan bagi investasi asing maupun domestik. Kedua, fase yang terkait dengan adanya booming harga minyak bumi tahun 1973-1981 dan ditandai dengan dibangunnya banyak industri, maupun tidak efisien. Pengaruh fase ini pada industrialisasi di Indonesia adalah meningkatkan pertumbuhan ekonomi yang cepat, sehingga permintaan domestik untuk barang manufaktur meningkat, oleh karena itu pemerintah mempercepat industrialisasi di Indonesia dengan membangun banyak industri besar yang padat modal. Disini terjadi Peristiwa 


\section{Journal of Indonesian Applied Economics \\ Vol. 2 No.1 Mei 2008, 68-89}

Malari tahun 1974, yang meluncurkan sentimen nasionalis dan anti modal asing sehingga berdampak pada kebijakan perdagangan yang proteksionis.

Fase ketiga ditandai dengan adanya awal permasalahan struktur dan efisiensi yang serius akibat penurunan harga minyak dunia, sehingga memaksa pemerintah untuk mengkaji ulang kebijakan industri dimana kebijakan tersebut membawa Indonesia kepada masalah pembayaran internasional. Pada fase keempat pemerintah mengubah investasi pemerintah, campur tangan pemerintah, dan industri substitusi impor menjadi investasi swasta yang berorientasi pasar dan berorientasi ekspor (Kuncoro, 2007). Secara lebih jelas, dapat dilihat pada penjelasan berikut ini:

\section{Periode Sampai Dengan Tahun 1966}

Pada era ini, pemerintah sangat mengintervensi dan memilih untuk berorientasi kedalam (inwardlooking) dalam mengembangkan strategi industri. Fokus perhatian pemerintah dititik beratkan pada BUMN yang bergerak dalam sektor manufaktur, yang didukung dengan kucuran kredit Perbankan, subsidi, dan valas. Namun, sedikitnya cadangan devisa nasional menyebabkan pemerintah menerapkan kontrol devisa yang pada akhirnya menyebabkan langkanya bahan baku dan suku cadang impor. Pada masa ini pula banyak terjadi privatisasi perusahaan domestik dan nasionalisasi perusahaan asing.

Selama masa ini terjadi ketidak stabilan politik, defisit anggaran yang tidak terselesaikan, inflasi yang melonjak, serta campur tangan pemerintah dalam pasar yang sangat kuat, sehingga menghasilkan lingkungan yang kurang kondusif bagi perkembangan industri nasional. Pemerintah pada saat itu mengambil langkah-langkah untuk mengambil alih sektor usaha yang dianggap strategis melalui kebijakan untuk menasionalisasikan perusahaan-perusahaan.

Langkah-langkah tersebut tidak bisa dilepaskan dari paradigma revolusi yang dicangkan oleh Presiden Soekarno, yaitu membangun karakter nasional Indonesia; National Character Building. Pemerintah terus berupaya untuk mencapai kemandirian ekonomi. Salah satu usaha yang dilakukan adalah penyusunan Rencana Urgensi Ekonomi (RUE), yang bertujuan mengembangkan industri manufaktur modern yang dikendalikan dan dikuasai oleh orang Indonesia. Menurut RUE, pembangunan industri dibiayai dahulu oleh pemerintah, kemudian diserahkan kepada pihak swasta melalui perusahaan patungan antara pemerintah dan swasta, namun RUE relatif gagal dalam penerapannya, sehingga pada tahun 1956 RUE digantikan Rencana Pembangunan Lima Tahun (Repelita) I untuk periode tahun 1956 - 1960 yang disusun oleh Biro Perancang Negara.

Pemerintah pada masa ini juga menyusun Program Banteng (1950) yang dilakukan melalui pengembangan wiraswasta pribumi yang tangguh dan menempatkannya pada sektor penting yaitu perdagangan impor, dibawah kendali nasional. Pelaksanaan program ini dilakukan dengan memberikan lisensi impor kepada pengusaha pribumi, dengan harapan pengusaha tersebut dapat menumpuk modal dan kemudian melakukan diversifikasi ke sektor usaha lainnya. Namun, meski $70 \%$ perdagangan impor dikuasai oleh pribumi, terjadi suatu kondisi dimana pihak penerima lisensi menjual lisensinya kepada pihak non pribumi terutama etnis Tionghoa, akibatnya program tersebut justru dimanfaatkan oleh para rent seeker yang mengambil keuntungan jangka pendek (Kuncoro, 2007).

Langkah-langkah yang ditempuh golongan nasionalis radikal terbukti berhasil menghapus dominasi bisnis Belanda atas ekonomi Indonesia, namun berbagai masalah ekonomi lainnya bermunculan seperti inflasi, merajalelanya pasar devisa gelap, dan masalah ekonomi lainnya. Investasi di bidang industri sangat kecil dan sebagian besar tak terselesaikan. Mayoritas industri pada masa ini merupakan industri kecil dan menengah pengolah bahan mentah, hampir tidak ada industri besar dan modern, dan investasi asing masih sangat jarang dilakukan.

\section{Periode Stabilisasi dan Rehabilitasi, 1967 - 1972}

Fokus kebijakan ekonomi pada periode ini adalah stabilisasi harga serta mengembalikan tingkat pertumbuhan. Pada dasarnya, periode ini diwarnai oleh pergeseran dari perekonomian tertutup ke arah perekonomian terbuka dan berorientasi pasar. Dorongan untuk membuka perekonomian lebih disebabkan oleh kemampuan pemerintah untuk membiayai perekonomian domestik yang terbatas. 
Hal itu membuat pemerintah harus memikirkan sumber-sumber pendanaan lain. Hal itu mendorong dilakukannya sejumlah deregulasi dan liberalisasi di sektor perdagangan, finansial dan investasi asing (Pangestu 1996).

Pemerintah melakukan sejumlah kebijakan yang menguntungkan sektor manufaktur, terutama liberalisasi perdagangan dan unifikasi nilai tukar (Poot, et.al, 1991). Prioritas utama ada pada pengembangan sektor swasta, dimana promosi banyak dilakukan untuk menarik investor asing ke Indonesia. Namun, subsidi pada perusahaan pemerintah mulai dihapuskan. Hasilnya adalah bahan baku dan suku cadang industri makin mudah ditemukan.

Periode ini ditandai oleh mulai bersentuhannya Indonesia dengan modal asing, baik modal pemerintah dari negara dan lembaga donor (IMF, Bank Dunia, IGGI), maupun investasi asing. Pengaruh dari kebijakan stablisasi cukup terasa pada kinerja perekonomian. Inflasi bisa ditekan hingga mendekati satu digit. Pertumbuhan ekonomi bisa dikembalikan ke tingkat positif. Bahkan secara rata-rata, pertumbuhan ekonomi di lima tahun pertama Orde Baru mencapai angka $10 \%$. Pengaruh terhadap kesejahteraan dan distribusi pendapatan juga positif. Keberhasilan kebijakan stabilisasi tersebut menyebabkan daya beli masyarakat meningkat serta kelangkaan barang dan jasa bisa diatasi hingga taraf tertentu. Hal ini berimbas pula pada perbaikan distribusi pendapatan ditunjukkan oleh penurunan nilai koefisien Gini yang menggunakan data konsumsi (Booth, 2000).

\section{Periode Boom Minyak, 1973 - 1981}

Di tahun '70-an, terutama setelah oil boom, sulit untuk mengatakan bahwa ekonomi Indonesia sebagai pro-pasar. Ini terlihat dari struktur ekspor serta pola kebijakan industrialisasi yang bertentangan dengan teori 'keunggulan komparatif' yang menjadi jargon pasar bebas. Kenyataannya, kebijakan industri tahun '70-an diwarnai dengan proteksi yang tinggi, serta pembangunan industriindustri berat yang justru bertentangan dengan keunggulan komparatif Indonesia yaitu industri berbasiskan tenaga kerja murah (Basri 2001).

Pendapatan dari boom minyak telah memberikan ruang bagi pemerintah untuk membiayai proyek-proyek ambisius yang padat modal maupun terlibat langsung dalam produksi. Penghasilan dari minyak juga telah menciptakan disinsentif bagi pemerintah untuk menjalankan kebijakan yang terbuka dan pro pasar. Pertumbuhan ekonomi di era boom minyak masih terjadi pada tingkat yang cukup tinggi, 7-8\% per tahun.

Bantuan khusus diberikan pada industri-industri dasar, namun tidak banyak perhatian yang diberikan pada pembangunan industri kecil. Selanjutnya terjadi perubahan prioritas dimana penciptaan lapangan kerja menjadi faktor utama, lalu diikuti dengan pengembangan industri bahan mentah domestik atau promosi yang berhubungan dengan pertanian dan infrastruktur.

Tetapi di sisi lain terjadi pemburukan distribusi pendapatan selama periode tersebut. Penyebabnya, seperti ditulis oleh Booth, 2000 adalah pertumbuhan ekonomi serta pengeluaran pemerintah yang bias secara tidak proporsional ke sektor modern, industri yang padat modal, serta daerah perkotaan. Ketimpangan semakin diperparah dengan adanya efek 'Ducth Disease', yang membawa apresiasi riil atas nilai tukar. Kondisi tersebut menyebabkan harga komoditas ekspor Indonesia menjadi kurang kompetitif. Akibatnya, penduduk yang tinggal di pedesaan, terutama yang bekerja di sektor pertanian serta sektor yang berorientasi ekspor semakin dirugikan.

\section{Periode Pasca Boom Minyak, 1982 - 1985}

Jatuhnya harga minyak di awal ' 80 -an menyebabkan pemerintah harus mencari sumbersumber pembiayaan dalam negeri yang lain. Yang dipilih adalah kebijakan liberalisasi sektor finansial pada tahun 1983. Pada periode ini pemerintah masih memprioritaskan penguatan struktur industri, setidaknya terdapat tiga fokus pengembangan kebijakan industri di Indonesia, yaitu: pengembangan industri subsitusi impor dengan pendalaman dan pemantapan struktur industri, pengembangan industri melalui penguasaan teknologi di beberapa bidang (pesawat terbang, mesin, dan perkapalan), dan pengembangan industri berorientasi ekspor. Pada dekade 1980-an industri manufaktur mulai berkembang, sebagai akibat kebijakan deregulasi pada sektor finansial. Deregulasi sendiri merupakan 


\section{Journal of Indonesian Applied Economics \\ Vol. 2 No.1 Mei 2008, 68-89}

hasil desakan ekspansi finance capital yang dispekulasikan atau diutangkan di beberapa negeri berkembang, karena akumulasi keuntungan sudah tidak dapat diinvestasikan lagi pada sektor produktif di negeri-negeri asal (kapitalis maju). Peran finance capital ini, selain melahirkan pembangunan jalan raya, pelabuhan, bendungan, infrastruktur lainnya, dan industri manufaktur, juga melahirkan praktek rent seeker besar-besaran.

Statistik juga mencatat bagaimana periode tersebut ditandai oleh pertumbuhan ekonomi yang tinggi hingga dekade ' 90 -an. Disini terlihat bahwa perubahan orientasi kebijakan ke arah pasar terjadi lebih karena pilihan yang pragmatis-rasional. Bukan karena alasan yang sifatnya ideologis. Seperti dikemukakan oleh Basri (2001):

Dalam era '70-an, ketika dana minyak tersedia dan peran kelompok nasionalis menguat, pilihan kebijakan yang non-pasar dan proteksionis ... memiliki harga yang relatif 'murah' dibandingkan kebijakan pro-pasar ... karena untuk memperoleh dukungan politik, pemerintah akan mengakomodasi tekanan kelompok kepentingan yang kuat pada waktu itu. Sedangkan di pertengahan 1980-an, ketika harga minyak jatuh ... pilihan kebijakan yang non-pasar menjadi relatif lebih 'mahal'...

Konotasi biaya yang 'mahal' atau 'murah' di sini didefinisikan sebagai biaya (usaha) dalam rangka mempertahankan legitimasi pemerintah Orde Baru. Jadi, ideologi di sini timbul sebagai 'akibat', dan bukan sebagai sebab. Perubahan kebijakan tersebut juga membawa pengaruh atas distribusi serta penurunan angka kemiskinan. Pendapatan minyak yang berkurang mendorong pemerintah melakukan perubahan orientasi kebijakan untuk mencari pembiayaan alternatif bagi pembangunan dan banyak memangkas pengeluaran.

Sejumlah deregulasi dan kebijakan reformasi dijalankan, antara lain kebijakan devaluasi riil, reformasi perpajakan, penggalakan ekspor non-migas serta investasi asing, efisiensi BUMN serta deregulasi finansial (Pangestu, 1991). Kebijakan yang dikenal juga sebagai 'Kebijakan Penyesuaian Struktural' (Structural Adjustment Policies) berhasil membawa sejumlah perbaikan dalam kinerja ekonomi, antara lain peningkatan ekspor non-migas, terutama sektor industri padat karya, yang menjadi penjelasan utama atas perbaikan distribusi dan angka kemiskinan.

Selain oleh utang luar negeri, praktek rent seeker juga kian disuburkan oleh kredit-kredit yang begitu mudahnya dikeluarkan oleh bank-bank dalam negeri. Utang-utang tersebut, kini menjadi jerat atau dijadikan instrumen untuk mengendalikan kebijakan ekonomi sesuai kehendak korporasi internasional. Selain itu masih harus dibayar oleh negara dengan pemotongan terhadap hak-hak rakyat akan jaminan kesejahteraan.

Modal yang masuk dalam bentuk utang dan spekulasi tadi, baik pada sektor pertambangan, manufaktur maupun yang sekedar berputar di pasar modal, tidak memberi landasan bagi industri yang mandiri, dan tanpa arah strategis yang jelas. Sampai saat ini, Indonesia masih harus membeli bahan baku setengah jadi hasil olah teknologi dari luar. Contohnya, hasil pertambangan bauksit masih harus dikirim ke Jepang untuk dapat diolah menjadi alumunium, dan banyak contoh lainnya. Mesin-mesin juga masih didatangkan dari luar, karena investasi yang masuk tidak berkepentingan memroduksi mother machine (induk mesin/mesin pencetak mesin). Satu-satunya perusahaan di Indonesia yang pernah memiliki induk mesin adalah PT. Texmaco Engeneering, namun tidak berlangsung lama karena bangkrut. Ketergantungan lainnya adalah terhadap pasar (dengan semboyan: orientasi ekspor), sementara seringkali kebutuhan dalam negeri belum terpenuhi. Dalam penetrasi modal tersebut, sektor pertanian menjadi sasaran praktek eksploitasi kota terhadap desa.

\section{Periode Liberalisasi, 1986 - 1997}

Dekade ini ditandai oleh sejumlah mixed signals. Di satu sisi, Orde Baru memberikan komitmen politis terhadap perdagangan bebas internasional dengan menyetujui AFTA, APEC dan WTO. Jargon 'liberalisasi perdagangan' yang semula dipandang sebagai anti-Pancasila (seperti halnya komunisme dan sosialisme), kini justru digunakan sebagai jargon politik dan kebijakan liberalisasi sektor perbankan. Namun struktur proteksi di sektor perdagangan internasional masih tetap tinggi hingga 1985-1986. Setelah proteksi perlahan-lahan diturunkan, barulah kita melihat peranan yang besar dari 


\section{Proses Industrialisasi di Indonesia}

Damayanthi

industri yang padat tenaga kerja. Untuk beberapa hal, Indonesia bahkan terlihat lebih banyak dan cepat memberikan komitmen terhadap globalisasi, antara lain ditunjukkan oleh dikeluarkannya paket liberalisasi investasi sektor riil (1994).

Namun di sisi lain, hadir pula kebijakan-kebijakan yang sangat intervensionis dan anti-pasar. Sebut saja Tata Niaga sejumlah komoditas serta pembentukan BPPC, proyek Mobil Nasional serta dukungan finansial dan politis yang begitu kuat kepada IPTN. Dalam periode ini, ekonomi tumbuh dengan laju yang cukup tinggi dan penurunan angka kemiskinan berlanjut. Namun elastisitas angka kemiskinan terhadap pertumbuhan ekonomi semakin kecil, atau pengaruh pertumbuhan ekonomi terhadap pengurangan kemiskinan berkurang. Ini menggambarkan bahwa pertumbuhan ekonomi ternyata diiringi dengan pemburukan distribusi pendapatan, sehingga memperkecil dampak dari pertumbuhan ekonomi terhadap penurunan angka kemiskinan. Booth (2000) memberikan beberapa penjelasan atas fenomena tersebut.

Pertama, pertumbuhan ekonomi sejak 1987 lebih banyak didorong oleh sektor modern dan manufaktur dan memarjinalkan peran sektor pertanian, dimana lebih dari $60 \%$ penduduk Indonesia bekerja. Kedua, terdapatnya kantong-kantong kemiskinan yang sulit dijangkau oleh kebijakan yang dilakukan pemerintah, yang letaknya tersebar di berbagai daerah pedesaan di Jawa dan luar Jawa. Alasan ketiga terkait dengan kebijakan pengeluaran pemerintah untuk sektor pendidikan, terutama untuk tingkat sekunder dan tersier yang cenderung bias pada penduduk yang relatif lebih mampu.

Saat industri manufaktur tumbuh pesat pada dekade ' 80 -an dan ' 90 -an awal, tenaga produktif pertanian sama sekali tidak berkembang. Industri hanya menyentuh sektor pertanian sebagai pasar, sehingga proyek-proyek di pedesaan pun dilakukan semata untuk memuluskan tujuan tersebut. Bila dilihat sekilas, pembangunan infrastruktur jalan raya, bendungan, pengenalan terhadap bibit dan pupuk jenis baru, tampak menguntungkan masyarakat desa. Namun, karena tujuannya bukan untuk memajukan pertanian maka, dampak yang dihasilkan pun merugikan dalam jangka panjang. Misalnya, dampak penggunaan pupuk pada kesuburan tanah, dll.

Ciri lain industri yang tumbuh saat itu adalah rendah teknologi sehingga, tidak membutuhkan tenaga kerja yang berketerampilan. Bidang pendidikan menerima ekses lanjutan dengan lemahnya perkembangan ilmu pengetahuan serta sistem pendidikan yang sama sekali tidak mengembangkan cara berpikir kritis.

Kelemahan dalam perkembangan tenaga produktif (teknologi dan sumber daya manusia), mengakibatkan rendahnya produktivitas serta penghasilan yang diterima buruh. Sebagai contoh, industri manufaktur menengah dan besar, hanya mempekerjakan empat juta tenaga kerja atau sekitar empat persen dari total 91 juta tenaga kerja. Perusahaan yang mempekerjakan 500 buruh ke atas mempekerjakaan sepertiga dari (kurang lebih 30 juta) tenaga kerja, memproduksi 80 persen dari nilai tambah manufaktur. Sementara dua pertiga (60 juta) tenaga kerja berada di perusahaan menengah dan kecil, yang mempekerjakan antara 5 sampai 99 buruh, serta industri rumah tangga yang mempekerjakan 1-4 buruh. Dua kategori yang disebut terakhir ini hanya menghasilkan nilai tambah manufaktur sebesar 5-6 persen. Sedangkan masalah penghasilan, menurut data Departemen Tenaga Kerja dan Transmigrasi, 85 persen buruh berpenghasilan di bawah 2 juta rupiah per bulan.

\section{Periode Krisis Dan Pemulihan, 1997 - 2004}

Periode krisis di Indonesia, dimulai pada tahun 1997. Krisis ini tentu berdampak besar pada sektor industri. Kebijakan yang diambil pemerintah dalam masa ini berorientasi pada inward dan outward looking. Sektor industri manufaktur Indonesia tumbuh jauh lebih lamban, dimana pada tahun 1997 hanya tumbuh sebesar 5,3\% dan tahun 1998 mengalami kontraksi sebanyak -11,4 \%.

Industri nasional kian menghadapi persoalan konkret sejak pemerintah menandatangani nota kesepahaman (Letter of Intent) dengan IMF tahun 1998. Butir-butir kesepahaman itu misalnya, liberalisasi ekspor yang berakibat pemenuhan energi dan bahan baku industri semakin sulit. Bila pun sanggup dipenuhi, harus diperoleh dengan harga tinggi sehingga biaya produksi melonjak. Masalah ini, misalnya, tampak pada industri kayu, keramik, pupuk, dll. Dalam hal sumber energi, sebagian besar hasil eksploitasi sumber energi seperti minyak, gas, dan batubara dijual ke luar negeri. Sekitar 90 persen dari total produksi gas nasional di ekspor ke luar negeri, sementara batubara mencapai 70 


\section{Journal of Indonesian Applied Economics \\ Vol. 2 No.1 Mei 2008, 68-89}

persen. Industri nasional juga menghadapi persoalan liberalisasi impor yang berdampak pada kalahnya produk dalam negeri dibanding produk impor yang lebih murah dan berkualitas. Persoalan lainnya adalah liberalisasi investasi yang mengakibatkan modal dapat berpindah dalam waktu singkat tanpa memperhatikan kebutuhan pembangunan jangka panjang.

Sejak krisis ekonomi di Asia sampai dengan tahun 2005, pertumbuhan sektor industri manufaktur hanya meningkat dengan laju 1 digit. Perkembangan yang tersendat-sendat ini jauh berbeda dengan masa sebelum krisis, pada saat sektor industri manufaktur dapat tumbuh dengan 2 digit. Selama kurun waktu 1994-1996, sektor industri manufaktur tumbuh dengan laju rata-rata 2 digit setahun, sedikit lebih rendah dibandingkan kurun waktu 1989-1993 (Kuncoro, 2007). Untuk lebih jelasnya dapat dilihat pada Tabel 1. dibawah ini:

Tabel 1. Pertumbuhan PDB dan Sektor Industri Manufaktur Indonesia, 1997-2005 (\%)

\begin{tabular}{l|ccccccccc}
\hline & $\mathbf{1 9 9 7}$ & $\mathbf{1 9 9 8}$ & $\mathbf{1 9 9 9}$ & $\mathbf{2 0 0 0}$ & $\mathbf{2 0 0 1} *$ & $\mathbf{2 0 0 2}$ & $\mathbf{2 0 0 3} * \boldsymbol{2 0 0 4} \boldsymbol{* *}$ & $\mathbf{2 0 0 5}$ \\
\hline PDB & 4,7 & $-13,1$ & 0,8 & 4,9 & 3,8 & 4,3 & 4,9 & 4,9 & 5,6 \\
Sektor Industri Manufaktur & 5,3 & $-11,4$ & 3,9 & 6,0 & 3,3 & 5,9 & 5,3 & 6,4 & 4,6 \\
Industri Migas & $-2,0$ & 3,7 & 6,8 & $-1,7$ & $-6,2$ & 2,5 & 0,6 & 12,9 & \\
Industri Non Migas & 6,3 & $-13,1$ & 3,5 & 7,0 & 4,9 & 6,4 & 5,4 & 10,6 & \\
\hline
\end{tabular}

Sumber: BPS dalam Kuncoro, 2007

Periode Pemulihan Dan Pengembangan, 2005 - 2009

Tahun 2005-2009 adalah masa pemulihan dan pengembangan industri setelah krisis. Revitalisasi, konsolidasi, dan restrukturisasi industri masih menjadi salah satu fokus pengembangan industri berkeunggulan kompetitif dengan pendekatan kluster (Departemen Perindustrian dan Perdagangan, 2005). Industrialisasi di Indonesia tidak bisa disamakan dengan negara industri baru di Asia Timur seperti Korea Selatan dan Taiwan. Cadangan sumber daya alam yang besar membuat sektor industri yang dibangun di Indonesia berbeda dengan negara-negara tersebut. Dimana naikturunnya harga minyak dunia sangat berpengaruh pada Indonesia. Indonesia memiliki kesamaan dengan India dan Cina, dimana sama-sama tidak memiliki pengalaman industrialisasi yang panjang, dan belum memiliki sektor permodalan yang baik, namun menjalankan transformasi industri yang bersifat outward looking.

Kuncoro, 2007 mengatakan bahwa dalam membahas industri di Indonesia, banyak hal penting yang harus diperhatikan, yaitu:

- Industri di Indonesia sangat beragam, mulai dari pertambangan besar di pedalaman hingga ribuan industri rumah tangga yang tersebar di seluruh pelosok negeri. Industri pertambangan membutuhkan tingkat investasi yang sangat besar, tingkat teknologi tinggi, beroperasi bertahuntahun, dan berpasar global. Sebaliknya, industri rumah tangga umumnya hanya memiliki modal kurang dari 1 juta rupiah, dikelola oleh keluarga, beroperasi musiman, menggunakan teknologi sederhana, dan hanya bersifat lokal. Dengan kata lain, kita salah jika menyebutkan 'sektor industri' sebagai sesuatu yang homogen.

- Penting pula untuk membagi industri Indonesia menjadi dua bagian besar, yaitu: industri sektor minyak dan gas, serta industri lain diluar sektor minyak dan gas.

Di masa ini, visi kebijakan industri adalah "Pada Tahun 2020, Indonesia Menjadi Negara Industri Baru". Dalam kebijakan perkembangan industri nasional, dicantumkan sasaran kualitatif dalam jangka menengah (2004-2009) dan jangka panjang (2010-2020), menurut Departemen Perindustrian, 2005 sasaran industri dalam jangka panjang mencakup:

- Kuatnya industri yang memiliki daya saing yang berkelanjutan. 
- Kuatnya struktur industri manufaktur, terutama antara industri kecil-menengah (IKM) dan industri besar.

- Seimbangnya sumbangan IKM terhadap PDB dibandingkan sumbangan industri besar.

- Terdistribusinya industri ke seluruh wilayah tanah air.

Secara umum, kebijakan industri dapat diklasifikasikan kedalam upaya sektoral dan horisontal (Cowling, 1999). Upaya sektoral terdiri atas berbagai macam tindakan yang dirancang untuk menargetkan industri-industri atau sektor-sektor tertentu dalam perekonomian. Upaya horisontal dimaksudkan untuk mengarahkan kinerja perekonomian secara keseluruhan dan kerangka persaingan dimana perusahaan-perusahaan melaksanakan usahanya. Agaknya, dimasa mendatang diperlukan kebijakan industri yang antisipatif atau proaktif dalam menghadapi banyak perubahan baik di lingkup nasional ataupun lingkup internasional.

Kuncoro, 2002 membuktikan bahwa pilihan kebijakan industri ini telah menyebabkan pertumbuhan yang sangat cepat pada usaha Industri Manufaktur Besar dan Menengah (IBM), dengan konsentrasi secara spasial di Jawa-Sumatera-Bali dan cenderung terkonsentrasi di tengah perkotaan; daerah kota metropolitan. Bahkan deregulasi dan liberalisasi sejak pertengahan 1980 an telah terbukti memperkuat konsentrasi spasial di Indonesia.

Maka akan sangat penting melakukan reformasi kebijakan industri nasional. Kebijakan industri tradisional sering dihubungkan dengan penentuan target sektor-sektor dan industri tanpa menghiraukan dimana sektor-sektor tersebut berlokasi dalam sebuah negara. Harus diakui, selama ini kebijakan industri Indonesia bersiafat aspasial; spaceless karena mengabaikan lokasi industri. Sebaliknya, perspektif baru kebijakan industri lebih mendukung tindakan-tindakan horisontal dan menolak target sektoral. Dalam konteks ini, perspektif spasial pembangunan industri dengan berbasis kluster merupakan salah satu faktor kunci yang dapat membantu pemerintah pusat dan daerah dalam merumuskan kebijakan industri.

\section{Hambatan, Tantangan, dan Peluang Industrialisasi di Indonesia}

Makna praktis industrialisasi adalah memajukan tenaga produktif menjadi lebih modern, dapat diakses secara massal, dan tinggi kualitas. Tanpa kemajuan tenaga produktif, negeri ini tidak akan punya ketahanan ekonomi menghadapi gempuran neoliberalisme. Tanpa ketahanan ekonomi, kedaulatan negeri ini -terutama kedaulatan rakyatnya- berhenti sebatas cita-cita.

Terdapat tiga variabel kerja pokok yang saling berhubungan dalam batasan tersebut, yaitu:

- Mengapa dan bagaimana program industrialisasi nasional dapat melindungi industri yang ada, sehingga tidak semakin hancur karena kalah bersaing di tingkat global, regional, maupun lokal (terhadap industri negeri-negeri yang lebih maju).

- Mengapa dan bagaimana program industrialisasi nasional dapat mengambil alih atau melakukan proses transfer kepemilikan atas sumber daya produksi vital, energi, teknologi dan ilmu pengetahuan, yang masih dikontrol oleh korporasi asing ke dalam kontrol negara (meski tidak harus berbentuk BUMN, melainkan lewat pengetatan kebijakan ekonomi).

Mengapa dan bagaimana program industrialisasi nasional dapat menciptakan dan mengembangkan sumber daya produksi baru. Pada tahap awal (sumber daya produksi baru tersebut), diciptakan dan dikembangkan menurut kebutuhan memajukan sektor-sektor produksi vital yang masih tertinggal dari segi teknologi dan sistem produksi seperti, tanaman pangan, perkebunan, perikanan, dan peternakan.

Tujuan pembangunan ekonomi Indonesia adalah menciptakan terjadinya transformasi ekonomi, dari sektor pertanian menuju ke sektor industri yang bersandarkan pada mekanisme pasar yang efisien. Dari sini muncul persoalan struktural dalam perekonomian Indonesia, yaitu:

- Belum dirumuskannya jenis industri dan produk yang hendak dikembangkan dan dijadikan andalan di masa depan secara tuntas. 


\section{Journal of Indonesian Applied Economics \\ Vol. 2 No.1 Mei 2008, 68-89}

- Sistem produksi dam distribusi ekonomi nasional masih mengandalkan pola proteksionisme sehingga menimbulkan distorsi pasar.

- Keberadaan sektor pertanian di Indonesia sangat memprihatinkan, dimana kontribusinya terhadap pembangunan nasional semakin turun, juga tidak menunjukkan adanya proses modernisasi dan keterkaitan dengan proyek industrialisasi yang dikerjakan.

- Peningkatan produksi belum sepenuhnya didukung oleh penggunaan input produksi yang efektif dan efisien.

- Perkembangan nilai tambah masih terkonsentrasi pada beberapa jenis industri, sehingga kurang adanya perluasan usaha dan diversifikasi produk.

- Regulasi yang ada kurang mendorong pembinaan untuk menciptakan nilai tambah.

- Kesinambungan keterkaitan antara industri hulu dan hilir kurang terjamin, sehingga cenderung melemahkan peningkatan produksi.

- Kemampuan manajerial dan skill yang relatif terbatas.

Menilik pada sejarah kehadirannya, seluruh industri termaju di Indonesia saat ini tidak berdiri di atas kebutuhan ekonomi dalam negeri, melainkan atas permintaan dan kebutuhan ekspansi modal asing. Bila dibandingkan, sistem yang berjalan sekarang hanya kelanjutan dari sistem ekonomi kolonial, yang sempat terinterupsi sejenak di masa revolusi kemerdekaan dan separuh masa pemerintahan nasionalis Soekarno. Latar belakang sebagai negeri yang perekonomiannya bergantung pada asing ini, membawa kerawanan yang sudah diramalkan sejak awal.

Pentingnya industrialisasi sebagai tahapan untuk mempercepat perkembangan ekonomi dengan mudah dapat dipahami. Namun untuk mengembangkannya memerlukan persyaratan yang cukup berat, setidaknya sama dengan usaha mempercepat perkembangan ekonomi pada umumnya yaitu: Memerlukan permodalan yang cukup besar; peningkatan kualitas sumberdaya manusia yang akan terlibat dalam industrialisasi berupa kertampilan dan keahlian yang makin bervariasi, pranata sosial yang memungkinkan manusia dapat mengambangkan daya kreatifitasnya atau daya inovatif pada khususnya; prasarana transportasi serta komunikasi yang lebih baik; pemasaran yang dapat diperluas, baik di dalam negeri maupun di luar negeri; perbaikan kelembagaan, baik birokrasi pemerintah; perbaikan organisasi dan manajemen yang didukung oleh lembaga keuangan bank dan non bank. Persyaratan-persyaratan tersebut ada yang dihitung secara kuantitatif dan adapula yang bersifat non material yang tidak dapat dikuantitatifkan.

Menurut Sargant Florence dalam Latief (2002), ada sembilan arah yang dapat diukur dalam setiap proses kearah pengembangan industri :

- Meningkatkan kesadaran akan pentingnya kegiatan industri dan jasa sebagai lawan kegiatan pertanian.

- Penerapan ilmu (seperti mekanisasi atau pemakaian bahan kimia) dalam pertanian, pertambangan, transportasi, dan industrialisasi itu sendiri dalam kaitannya dengan investasi yang dilaksanakan.

- Perkembangan yang proporsional antara para organisator, manajer, penelitian, teknisi, dan staf administratif dibandingkan dengan kerja yang nyata dalam industri.

- Meluasnya pasar dan sumber supply sebagai akibat penerapan ilmua dibidang transportasi dan komunikasi, khususnya perluasan industri manufaktur dan lokalisasi industri-industri tertentu antar negara atau antar daerah dalam suatu negara.

- Sebagai konsekuensi dari ciri di atas, maka terjadinya diferensiasi industri manufaktur tertentu yang berbeda karakteristiknya.

- Terjadi urbanisasi, sebagai akibat pertumbuhan kota-kota industri dan daerah masyarakat perkotaan yang luas, lebih cepat dari perkemabangan penduduk pada umumnya.

- Perluasan besarnya unit organisasi industri seperti pabrik-pabrik dan perusahaan. 
- Mendesaknya penguasaan hirarki atau susunan berjenjang pada manajemen puncak dibidang industri. Bahkan dalam perekonomian kapitalis, permodalan itu sendiri menjadi kurang penting. Dalam perkembangan industri, bentuk-bentuk perusahaan perseorangan jumlahnya semakin kecil.

- Walaupun terjadi fluktuasi atau gelombang naik-turunnya kehidupan ekonomi, standar kehidupan penduduk yang lebih tinggi dapat tercapai.

Secara garis besar, persoalan-persoalan yang dihadapi tersebut di atas kurang lebih dapat diatasi lewat langkah-langkah industrialisasi sebagai berikut:

- Negara harus menjamin tersedianya sumber energi yang memadai untuk seluruh jenis industri. Korporasi-korporasi penghasil energi (minyak, gas, dan batu bara) harus diambil-alih kepemilikan ke tangan negara untuk memastikan tercukupinya kebutuhan energi dalam negeri. Sebaliknya, kerja sama energi dengan negeri-negeri seperti Venezuela dan Iran perlu ditingkatkan. Sejalan dengan itu, pemboyongan sumber energi ke luar harus dihentikan atau dibatasi.

- Sebagai antisipasi jangka panjang, dibutuhkan kajian-kajian strategis terhadap sumber energi alternatif dengan dampak negatif seminim mungkin terhadap lingkungan hidup.

- Negara harus menjamin tersedianya bahan baku yang cukup untuk seluruh jenis industri Penyedia kebutuhan primer masyarakat (sandang, pangan, papan). Perlu segera memperhatikan pengadaan sumber bahan baku yang sampai saat ini masih diimpor, seperti kapas untuk industri tekstil, dan juga sebagian produk pertanian (mengenai pertanian terdapat poin tersendiri). Larangan ekspor dikenakan terhadap jenis bahan baku yang menjadi basis bagi produksi kebutuhan primer masyarakat, sejauh tidak terdapat surplus yang bisa dipasarkan ke luar negeri.

- Kebijakan strategi industri dengan sektor swasta harus menghasilkan pembangunan industri pengolahan bahan baku menjadi bahan baku setengah jadi. Termasuk di dalamnya, membangun industri induk mesin, industri kimia, industri baja olahan, alumunium, dan lain sebagainya. Transfer teknologi dilakukan melalui kerja sama investasi dengan negeri yang memiliki teknologi lebih maju, atau 'mengadopsi' teknologi yang dipelajari dari luar negeri (Jerman, Jepang, Rusia, Cina, dll).

- Negara menjamin tersedianya pasar bagi industri yang masih membutuhkan proteksi dengan pengenaan pajak atau cukai yang tinggi terhadap komoditi sejenis, yang diimpor dari luar negeri. Untuk jenis komoditi tertentu, perlu disediakan jalur distribusi yang dapat diakses oleh masyarakat luas dengan harga yang disubsidi.

- Tersedianya sumber daya manusia yang berkualitas. Dalam konteks ini, pendidikan dan kesehatan ditanggung sepenuhnya oleh negara. Jaminan penyediaan gizi bagi masyarakat, tidak dipandang sebagai program belas kasihan untuk sebagian rakyat miskin (seperti program BLT atau raskin yang dilakukan pemerintah saat ini). Kebutuhan yang sangat mendasar tersebut harus diberlakukan secara umum sehingga, dapat diakses oleh seluruh warga negara. Pengecualian hanya berlaku bagi warga negara yang memiliki kemampuan lebih sehingga, memilih akses terhadap pendidikan dan kesehatan di luar fasilitas yang disediakan oleh negara.

- Memajukan tenaga produktif pertanian dengan cara: a) mengalokasikan kredit yang memadai dengan jaminan oleh pemerintah dan bunga rendah kepada petani melalui bank pertanian; $b$ ) mobilisasi potensi seluruh lembaga riset pertanian untuk mengembangkan teknologi pertanian yang sesuai dengan karakter geografis dan sosial-budaya Indonesia. Pengembangan tersebut meliputi masalah pembibitan, mekanisasi proses tanam dan panen, pengairan, listrik, serta infrastruktur lainnya; c) mendorong terbangunnya contoh pertanian kolektif dengan pengolahan lahan bersama serta penerapan teknologi yang lebih maju. Penggarapan ini dilakukan secara demokratis dengan melibatkan petani dalam mengambil keputusan, baik saat 


\section{Journal of Indonesian Applied Economics \\ Vol. 2 No.1 Mei 2008, 68-89}

proses produksi maupun pemasaran; d) mengembangkan industri pengolahan hasil pertanian dalam setiap batasan teritori tertentu sesuai dengan komoditi pertanian yang diproduksi. Perlu dijelaskan, program teknologisasi pertanian ini tidak akan menciptakan pengangguran baru, sebaliknya akan membuka lapangan kerja. Karena dari setiap pengembangan tenaga produktif akan membutuhkan tenaga-tenaga kerja baru.

- Ijin operasi industri hulu harus disertai syarat pembangunan industri pengolahan sehingga bahan mentah ekstraktif tidak langsung dijual ke luar negeri. Dengan pengolahan tersebut, selain akan meningkatkan nilai tambah, juga akan meningkatkan produktivitas masyarakat lewat industri-industri pengolahan yang terbangun. Misalnya; hasil tambang bauksit yang diolah menjadi alumunium, bijih besi menjadi baja, baja menjadi mesin,dll.

- Memberikan perhatian terhadap industri kecil dan menengah dengan sarana dan kemudahan akses terhadap kredit mikro, bahan baku produksi yang murah, serta jaminan ketersediaan pasar.

\section{DAFTAR PUSTAKA}

Alt, James E dan Chrystal, K. Alec. 1983. Political Economics. Berkeley: University Of California Press.

Anonim, 1993. The East Asian Miracle: Economic Growth And Public Policy. World Bank Policy Research Report. New York: Oxford University Press.

Anonim. 2004. Adakah Perubahan Konsentrasi Spasial Industri Manufaktur Di Indonesia, 19762001? Jurnal Ekonomi Dan Bisnis Vol 19 No. 4 Oktober 2004.

Anonim. 2004. Kebijakan Pasar Tenaga Kerja Dan Hubungan Industrial Untuk Memperluas Kesempatan Kerja. www.smeru.or.id

Arifin, Bustanul. 2006. Refleksi: Interaksi Birokrasi Dengan Dunia Usaha. Bisnis \& Ekonomi Politik Vol 7 (3) Juli 2006

Arifin, Zainal dan Mudrajad Kuncoro. Konsentrasi Spasial Dan Dinamika Pertumbuhan Industri Manufaktur Di Jawa Timur. www.mudrajad.com

Basri, M. Chatib. 2001. Modal dan Kekuasaan: Sebuah Fenomena Schindler's List? (mimeo).

Booth, Anne. 2000. "Survey of Recent Development". BIES 36/1:73-104 (April 2000).

Carpenter, Daniel. 2001. Lesson, Portraiture, Method, Myth: Richard Bensel's The Political Economy of American Industrialization, 1877-1900. University Of Michigan.

Chandra, Aditiawan. 2001. Relokasi Industri Perusahaan Global Di Negara Sedang Berkembang. Usahawan No. 10 Tahun XXX Oktober 2001.

Cohn, Theodore. H. 2003. Global Political Economy: Theory And Practise Second Edition. New York: Addison Wesley Longman Inc.

Coleman, D.C. 1966. "Industrial Growth and Industrial Revolutions" in E.M, Carus-Wilson. Essays in Economic History (volume 3). London: Edward Arnold Publishers Ltd.

Dwijowijoto, Riant Nugroho. 2003. Reinventing Pembangunan Menata Ulang Paradigma Pembangunan Indonesia Baru Dengan Keunggulan Global. Jakarta: Elex Media Komputindo.

Gallion, Arthur B dan S. Eisner. 1986. The Urban Pattern: City Planning and Design. Terjemahan Sussongko dan Januar Hakim. Jakarta: Penerbit Erlangga. 
Hasan, Bakir. 2001. Antisipasi Era Sumberdaya Informasi. Majalah Perencanaan Pembangunan Edisi 24 Tahun 2001.

Hanson, J.L. 1969. An Introduction To Applied Economics. London: MacDonald And Evans, Ltd.

Helibroner, Robert. 1972. The Making of Economic Societ. New York: Prentice-Hall.

Hill, Hal. 2000. The Indonesian Economy Since 1966, New York: Cambridge. . 1997. Indonesia's Industrial Transformation. Singapore: ISEAS.

Krueger, Anne O. 1985. "The Experience and Lessons of Asia's Super Exporters" in Vittario Corbo, Anne O. Krueger, and Fernando Ossa edited. Export-Oriented Development Strategies: The Success of Five Newly Industrializing Countries. Boulder and London: Westview Press.

Kumar, Nagesh dan Gallagher, Kevin P. 2006. Relevance Of "Policy Space” For Development: Implication For Multilateral Trade Negotiations. www.ris.org.in

Kuncoro, Mudrajad. 2007. Ekonomika Industri Indonesia Menuju Negara Industri Baru 2030 ?. Yogyakarta: Penerbit Andi.

Kuncoro, Mudrajad. 2004. Otonomi Dan Pembangunan Daerah: Reformasi, Perencanaan, Strategi, Dan Peluang. Jakarta: Erlangga.

Kuncoro, M. 2000. “Beyond Agglomeration and Urbanization”. Gajah Mada international Journal of Business. September 2000.Vol.2.No.3, pp.307-325.

Kuncoro, M. 2004. Kata Pengantar. Buku Industri \& Orientasi Ekspor Karangan Dr. M. Wahyudin. http://www.mudrajad.com

Kuncoro, Mudrajad. 2005. Menanti Reformasi Iklim Bisnis Di Indonesia. www.mudrajad.com

Kompas. 2000. “Kebijakan Nasional Sektor Industri: Aglomerasi dengan kemitraan”. 19 Agustus 2000.

Lim, Suk-Jun, 19xx. Politics Of Industrialization: Formation Of Divergent Industrial Orders In Korea And Taiwan. www.uchicago.edu

McIntyre, Andrew. 1990. Business and Politics in Indonesia. Sydney: Allen\&Unwin.

Oktavianus, Dominggus. 2007. Industrialisasi Nasional dan Cita-Cita Kemakmuran. http:// www.indoprogress.blogspot.com

Pangestu, Mari E. 1996. Economic Reform, Deregulation and Privatization: the Indonesian Experience. Jakarta: CSIS.

Perdana, Ari A. 2001. Peranan 'Kepentingan'Dalam Mekanisme Pasar Dan Penentuan Kebijakan Ekonomi Indonesia. Economics Working Paper Series.

Robison, Richard. 1990. Power and Economy in Suharto's Indonesia. Manila: Journal of Contemporary Asia Publisher.

Yustika, Ahmad Erani. 2007. Perekonomian Indonesia: Satu Dekade Pasca Krisis Ekonomi. Malang: Badan Penerbit Fakultas Ekonomi Universitas Brawijaya. 